\title{
Az eredményalapú ügyfélélmény-mérési módszer alkalmazósa B2B piacon
}

\author{
Gyulai Zsófia - Révész Balázs \\ Szegedi Tudományegyetem
}

\begin{abstract}
A TANULMÁNY CÉLJA
Tanulmányunkban azt a kérdéskört vizsgáltuk, hogy egy business-to-business kapcsolat ügyfélélményét befolyásolhatja-e a szolgáltató által az igénybe vevő számára létrehozott érték. Kutatásunk során egy listing portál és egy integrált webhelyanalitikai szolgáltatást nyújtó szolgáltatott szoftver kapcsolatát tanulmányoztuk.
\end{abstract}

\begin{abstract}
ALKALMAZOTT MÓDSZERTAN
Tanulmányunkban az ügyfélélmény-mérés egy holisztikus és nagyon újszerủ megközelítését alkalmaztuk, az eredményalapú ("outcomes-based”) mérési módszert, amely csupán néhány éve jelent meg a marketing szakirodalomban. Az új mérési módszer lényege, hogy hagyományos elégedettségmérések során megszokott kérdés helyett (Tetszett az adott termék vagy szolgáltatás a fogyasztónak?) arra a kérdésre keressük a választ, hogy milyen változást idézett elő a termék használata, vagy a szolgáltatás igénybevétele $\mathrm{B} 2 \mathrm{C}$ piacon a fogyasztó életében, B2B piacon a vállalat működésében (Burkett 2013, Zolkiewski et al. 2017). A fogyasztói vagy felhasználói élmény B2B piacokon még összetettebb jelenség, mint a B2C piacok esetében, így különböző adatgyüjtési módszerek kombinációja jobb eredményeket nyújthat (Biedenbach \& Marell 2010, Zolkiewski et al. 2017). A jobb eredmény elérése érdekében vegyes adatgyüjtést alkalmaztunk mennyiségi és minőségi webhelyanalitikai adatok változásának megfigyelésével, valamint szakértői triád interjúkkal.
\end{abstract}

\section{LEGFONTOSABB EREDMÉNYEK}

A hagyományos ügyfélélmény-mérési módszerek alapján az ingatlanportál elégedettlen volt az integrált webanalitikai szolgáltatással és egységes ügyfélélményt kizárólag az ügyfélszolgálat idézett elő a vállalatnál. Ezzel szemben a szolgáltatás használatának kimenetelit tanulmányozva az ingatlanportál munkatársai elégedettek voltak a szolgáltatással, hasznosnak ítélték meg azt. A webhelyanalitikai adatok alapján a szolgáltatás nagymértékben hozzájárult az ingatlanportál ügyfélélményének kialakításában.

\section{GYAKORLATI JAVASLATOK}

A tanulmány újdonsága az alkalmazott módszertanban, az eredményalapú ügyfélélmény-mérési módszerben rejlik. Segítségével a vállalatok összetettebb képet kaphatnak az ügyfelek elégedettségéről, mivel holisztikusan vizsgáljuk azt.

Kulcsszavak: eredményalapú ügyfélélmény-mérés, B2B marketing, felhasználói élmény

Köszönetnyilvánitás: Az innovációs és technológiai minisztérium ÚNKP-19-3 kódszámú Új Nemzeti Kiválósági Programjának szakmai támogatásával készült.

DOI: 10.15170/MM.2020.54.KSZ.III.03 


\section{BEVEZETÉS INTRODUCTION}

Az ügyfélélmény egyike napjaink leggyakrabban használt marketing fogalmainak. Népszerüségét elsősorban az online fogyasztói piacon szerezte, de mára már a szervezeti piacok marketingjében is előkelő helyet vívott ki magának. A marketing területén sokáig a szervezetek vásárlói magatartása és az ipari marketing fogalmakkal illetett B2B marketing az elmúlt három évtizedben jelentős fejlődésen ment keresztül. Az eredetileg csak az alapanyag beszerzésre, illetve az ipari eladók és vevők közötti tranzakciókra fókuszáló terület súlya a szolgáltató és technológiai szektor megerősödésével vált igazán jelentőssé és teljesen elfogadottá. A B2B marketing kifejezés használata tágabb értelemben magában foglalja a vállalatok, kormányzati szervek és nonprofit szervezetek összes értékteremtő kapcsolatát is (Lilien 2016).

A hagyományos B2B beszerzési folyamat során a személyes kapcsolatok és tapasztalatok játszották a fö szerepet (Shaw 2007). A hagyományos B2B marketing a megfelelő szolgáltatás nyújtás és a szolgáltatás minősége, valamint a hatékony árképzés révén biztosított ügyfélélményt. Napjainkban azonban növekvő igény mutatkozik a B2C marketingből ismert olyan élményt teremtő marketing megoldások iránt, mint pl. a személyre szabás, vagy az online értékelési rendszerek alkalmazása (Biedenbac \& Marell 2010, Wollan 2016).

\section{IRODALMI ÁTTEKINTÉS LITERATURE REVIEW}

\section{Az ügyfélélmény (CX) jelentösége a B2B piacon \\ The importance of customer experience (CX) in the B2B market} A közgazdászokat már az 1950-es években is fog-
lalkoztatta, hogy mit akar a vásárló. Abbott (1955)
szerint nem a termék, vagy a szolgáltatás, hanem
az (ügyfél)élmény áll a fogyasztó gondolkodásá-
nak homlokterében. Schmitt (1999) öt féle élményt
határozott meg, az érzékszervi, érzelmi, kognitív,
fizikai és a szociális-identitás élményt, amelyek
mindegyike hozzájárul a pozitív vásárlói úthoz
(Lemon \& Verhoef 2016). A vásárlói út azokat az
aktivitásokat, interakciókat tartalmazza, amelynek
során az ügyfél eljut a vásárlásig (vagy akár az
újra vásárlásig is). A vásárlói út térkép (customer
journey map) elösegíti a vásárlói interakciók során alkalmazott érintkezési pontok ábrázolását és rendszerezését annak érdekében, hogy megértsük, hogy a vásárlók milyen módon tájékozódnak és menynyire elkötelezettek a vállalat iránt (Richardson 2010). Az ügyfélélmény biztosításában különösen fontos szerepet játszanak ezek az érintkezési pontok, hiszen a vásárlói út során a vásárlók vállalattal kapcsolatos érzelmei és élményei folyamatosan változnak, melyeket szintén tükröznek a vásárlói út térképek (Rosenbaum et al. 2017).

$\mathrm{Az}$ erős, pozitív ügyfélélmény növelheti a vásárlók minőségérzetét és hatással lehet a vállalat által nehezen kontrollálható jelenségekre, mint például a márkáról vagy a vállalatról szóló online, közösségi média posztokra, felhasználói véleményekre. Hosszútávon az erős pozitív ügyfélélmény segítségével egy lojális ügyfélbázis alakítható ki, amely a pozitív szájreklám révén is támogathatja a vállalatot (Lemon \& Verhoef 2016, Summe 1985).

$\mathrm{Az}$ élmények keresése napjainkban egyre népszerübb és már nem is csak a $\mathrm{B} 2 \mathrm{C}$ piacokon. A vevők még a vállalati beszerzések során is pozitív élmények szerzésére törekednek, melyet nagymértékben befolyásol a technológiai fejlődés és a vizualitás felértékelődése (Törőcsik 2007, Wollan 2016). Hasonló tendenciát figyelhetünk meg az online interfészek és szoftverek használatakor. A felhasználók nem csupán használni szeretnék a szoftvert, hanem élvezni is szeretnék a használatot (Bibi et al. 2012, Wollan 2016).

Az ügyfélélmény fogalmának többféle meghatározását is fellelhetjük a szakirodalomban. Kutatásunk során Biedenbach és Marell $(2010,450)$ megközelítését alkalmazzuk, amely szerint az ügyfélélmény nem más, mint ,, a vevö és a márka közötti teljes interakció és a kapcsolat észlelt értékének vevö általi interpretációja". Az ügyfélélmény tehát növeli a vevőnek nyújtott értéket.

A kutatások azt mutatják, hogy a B2B szervezetek számára is egyre fontosabb az ügyfélélmény kezelése. A fenntartható növekedés biztosítása kevésbé hatékony pusztán a termék- és árdifferenciálás alkalmazásával. A vállalatok új megoldásként az ügyfélélmény növelését célzó, korábban inkább csak a B2C piacokon használt megoldásokat adaptálnak (Wollan 2016).

Különösen igaz ez a Software-as-a-Service (SaaS) forgalmazókra. A SaaS vállalatok vezetóinek újra kell gondolnia az ügyfélélmény jelentőségéről alkotott véleményüket (Bonfiglio et al. 2017), hiszen a SaaS szolgáltatók üzleti és szolgáltatási modellje szerint a felhasználók a web böngésző vagy applikációk segítségével közvetlenül a szolgáltató felületeit és rendszereit használják. A megoldás előnye, hogy az adatok tárolására a 
szolgáltatónál kerül sor, így az ügyfél vállalat alkalmazottai akár egyidejüleg is többen tudják használni azokat (Benlian et al. 2011).

\section{Az érintkezési pontok szerepe az ügyfélélmény kialakításában The role of touchpoints in creating the
customer experience}

A felhasználók számos érintkezési pontot használva lépnek kapcsolatba a vállalattal (Lemon \& Verhoef 2016). Az ügyfél-márka találkozások sorozatát időben három szakaszra bonthatjuk Rosembaum és szerzőtársai (2017) szerint,

1. szolgáltatást megelőző időszakra,

2. szolgáltatási időszakra,

3. szolgáltatás utáni időszakra.

A szolgáltatást megelőző időszak során a potenciális vásárló reklámok vagy a többi vásárló ajánlásai révén találkozik a márkával (Rosenbaum et al. 2017). Ebben az időszakban még csak informálódik a problémamegoldás lehetőségeiről, gyakran még nem is tudatosan a márkára irányul az információgyüjtés. A szolgáltatási időszakban azonban már ügyfélként lép fel az érdeklődő. Ebben a szakaszban az interakció minden aspektusa pl. a termék kialakítása, a potenciális vásárló hangulata, az eladószemélyzet, a webáruház és a potenciális vásárló minden érzése, gondolata befolyással lehet a vásárlás kimenetelére (Benlian et al. 2011, Rosenbaum et al. 2017). A szolgáltatás utáni időszak a vásárlás utáni folyamatokat foglalja magába. Beletartozik a termék használata, a vevő által megfogalmazott ajánlások elkészítése és azok megosztása is a közösségi médiában (Rosenbaum et al. 2017).

Az ügyfél-márka találkozásokat aszerint is csoportosíthatjuk, hogy a vállalat által birtokolt, irányított vagy éppen a vállalattól független találkozási pontok révén jönnek-e létre. Ennek megfelelöen megkülönböztetünk direkt és indirekt ügyfél-márka találkozásokat. A direkt érintkezési pontok legtöbbször a szolgáltatási időszakban, a vásárlási interakció során illetve a vásárlást követően, a termék használata során aktivizálódnak. A vállalat befolyásolni, irányítani tudja a direkt érintkezési pontokat, például meghatározhatja a reklámok, az értékesítés vagy éppen a szolgáltatás nyújtásának helyét, hatással lehet az alkalmazottak viselkedésére, vagy a szolgáltatás más összetevőjére. Az indirekt érintkezési pontokra azonban nem tud közvetlen hatást gyakorolni a vállalat, így csak áttételesen tudja befolyásolni a közvéleményt, a szájreklám terjedését, vagy éppen a márkához kapcsolódó érzések és asszociációk körét (McColl \& Kennedy et al. 2015, Meyer \& Schwager 2007).

Az információs technológia fejlődése megsokszorozta a potenciális vásárlók számára elérhető digitális csatornákat. Az internet és a közösségi média terjedésével számtalan új érintkezési pont jött létre, amely a vevők és a vállalat, illetve a vevők és a márka közötti kapcsolatot megteremti. Ez egyúttal a vállalatok számára nehezen kontrollálható indirekt érintkezési pontok jelentőségének felértékelődéséhez is vezetett, hiszen az online közvélemény a blogok, közösségi média segítségével a vállalattól függetlenül terjeszti a márka jó vagy kevésbé jó hírét (Edelman \& Singer 2015, Lemon \& Verhoef 2016).

A vállalatok számára különösen fontossá vált a direkt és indirekt érintkezési pontok nyomon követése és az így begyüjtött adatok alapján az ügyfélélmény fejlesztése, az ügyfélszerzés és megtartás, azaz a hosszú távú siker biztosítása érdekében.

\section{MÓDSZERTAN METHODOLOGY}

Kutatásunk esettanulmány jellegü, két jól müködő vállalat -egy listing portál és egy szolgáltatott szoftver- kapcsolatát tanulmányoztuk. A kutatás fő célja az volt, hogy megvizsgáljuk, hogy B2B piacokon az adott szolgáltatás igénybevételén túl hogyan befolyásolja az elégedettségre gyakorolt hatást a szolgáltatás használatából eredő forgalom- és konverzió-változás.

A vásárlói élmény és az elégedettség mérése a $\mathrm{B} 2 \mathrm{~B}$ piacokon bonyolultabb, mint a $\mathrm{B} 2 \mathrm{C}$ piacok esetében. A B2B piacon nemcsak több az érintkezési pont, de mivel több szereplö is részt vesz a beszerzési és szervezési tevékenységek mindkét oldalán, ezért a kutatóknak több szempontból is meg kell vizsgálniuk a folyamatokat. A fogyasztói élmény mérése a marketingkutatás egy kiemelt területe, különösen az online szolgáltatások esetében, a kutatások nagy része azonban a B2C ügyfélélményre összpontosít (Biedenbach \& Marell 2010, Zolkiewski et al. 2017).

A felhasználói élmények és tapasztalatok adatgyüjtésének leggyakoribb eszköze a kérdőíves megkérdezés, az interjú, valamint az online és offline megfigyelés (Zolkiewski et al. 2017). A fogyasztói vagy felhasználói élmény összetett jelenség, így különböző adatgyüjtési módszerek kombinációja jobb eredményeket nyújthat. A jobb eredmény elérése érdekében vegyes adatgyüjtést alkalmaztunk mennyiségi és minőségi webhelyanalitikai adatok változásának megfigyelésével, valamint szakértői triád interjúkkal. 
Kutatásunkban az "outcomes-based”, vagyis eredmény-alapú teljesítménymérési módszert alkalmaztuk az ügyfélélmény által nyújtott értékek rögzítésére. Kutatásunk során megvizsgáltuk a közvetlen és közvetett márka-felhasználói interakciók által létrehozott értékeket.

Kutatásunk során két jól müködő vállalat B2B kapcsolatát vizsgáltuk egy adott szolgáltatás igénybevételekor. A szolgáltató oldalán egy szolgáltatott szoftver ("Software-as-a-Service" vagy "SaaS") áll, amely mennyiségi és minőségi webhelyanalitikai adatokat nyújt weboldalak számára. A szoftver betekintést nyújt a weboldalak tulajdonosainak arról, hogy a felhasználói pontosan mit és miért csinálnak a weboldalukon. Ehhez ún. hőtérképeket (heatmap), munkamenet visszajátszásokat (session replay), konverziós tölcséreket, valamint mennyiségi adatokat (pl. munkamenetek száma, visszafordulási arány, visszatérő felhasználók aránya...stb.) bocsát a szolgáltatás igénybe vevőinek rendelkezésére a SaaS.

A szolgáltatás igénybe vevője egy ingatlanportál volt, amely a webhelyanalitikai adatok hatására egy teljeskörü redesign-t hajtott végre a weboldalon 2018-ban.
Burkett (2013) azt javasolja, hogy a hagyományos elégedettségmérések során megszokott kérdés helyett (Tetszett az adott termék vagy szolgáltatás a fogyasztónak?) azt a kérdést tegyük fel, hogy milyen változást idézett elő a termék használata, vagy a szolgáltatás igénybevétele $\mathrm{B} 2 \mathrm{C}$ piacon a fogyasztó életében, B2B piacon a vállalkozás működésében. A felhasználói élmény kutatások fókuszában eddig az állt, hogy felhasználó elégedett-e az adott termékkel vagy szolgáltatással, a vállalat kommunikációjával, illetve az üzlet vagy webhely kialakításával, az eredmény alapú kutatás viszont azt is figyelembe veszi, hogy az adott termék vagy szolgáltatás hasznot hoz-e a felhasználónak.

Kutatásunk két szakaszból állt. Az első szakaszban megvizsgáltuk, hogy a szolgáltatott szoftver használata milyen hatással volt az igénybe vevő vállalat elégedettségére, tehát hagyományos elégedettségmérési kutatást végeztünk (1. ábra). A kutatás első szakaszához a SaaS által rendelkezésünkre bocsátott minőségi webhelyanalitikai adatok megfigyelése, valamint az igénybe vevő vállalat tulajdonosával és termékmenedzserével készített triád interjú nyújtotta az adatokat.

\section{1.ábra: A kutatás módszertana \\ Figure 1. Research methodology}

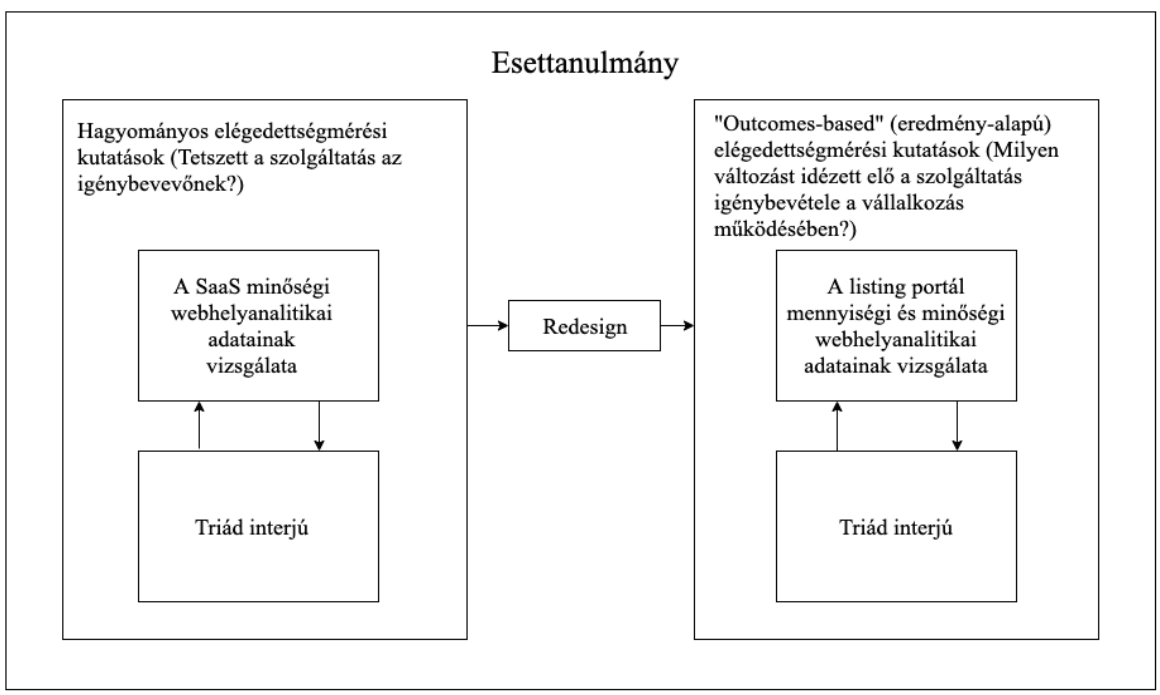

Forrás: Zolkiewski et al. 2017 módszertana alapján saját szerkesztés 
A kutatás második szakaszában azt vizsgáltuk, hogy a szolgáltatás igénybevétele miatt milyen változások következtek be a vállalat életében. A kutatás ezen szakaszában összehasonlítottuk a listing portál mennyiségi és minőségi webhelyanalitikai adatait a szolgáltatott szoftver igénybevétele előtt, valamint a szoftver kimutatásai miatt elvégzett változtatások után. Az adatok elemzését ebben a szakaszban is egy triád interjúval egészítettük ki, hogy pontosabb képet kapjunk a vállalat életében bekövetkezett változásokról. A triád interjú résztvevői a kutatás ezen szakaszában is a vállalat tulajdonosa és termékmenedzsere volt.

\section{EREDMÉNYEK RESULTS}

A kutatás első szakaszának elvégzéséhez a webhelyanalitikai szolgáltatást nyújtó vállalat az ingatlanportál beleegyezésével rendelkezésünkre bocsátotta azokat a munkamenet felvételeket, valamint hőtérképeket, amelyek a szolgáltatott szoftver felületén készültek az ingatlanportál általi használatról. Ezek a hőtérképek és felvételek segítették a triád interjút, a felhasználók könnyebben viszszaemlékeztek a szolgáltatás igénybevételére. A triád interjú során kiderült, hogy az ingatlanportál a weboldal átalakításának megalapozásához használta fel a minőségi webhelyanalitikai adatokat. A szolgáltatás igénybe vevői, amikor először látták a webhelyanalitikai eszköz weboldalát "termékközpontúnak” ítélték meg azt, mivel a szolgáltatott szoftver weboldala "nem azt hangsúlyozza ki a szolgáltató, hogy az adott funkció milyen hozzáadott értéket tudna nyújtani az igénybe vevönek, hanem a funkciók részletes termékleírása található meg a föoldalon". A szolgáltatás (akkor még potenciális) igénybe vevői később viszont a weboldalon kialakított blog, valamint esettanulmányok által “vevőközpontúnak, tanító jellegünek és professzionálisnak" ítélték meg az integrált webhelyanalitikai szolgáltatást. Az ingatlanportál termékmenedzserének első munkameneteiről készült felvételt közösen elemeztük a triád interjú során, amelyen jól kivehető volt, hogy az interjúalany sokat időzött az előfizetési csomagok összehasonlításánál, valamint a szolgáltatás beállításainak leírásánál. Elmondása szerint bizonyos leírások, magyarázatok bonyolultnak bizonyultak helyenként. Az ingatlanportál számára a szolgáltatott szoftver ügyfélszolgálati munkatársainak kedvessége és segítőkészsége nyújtotta a legnagyobb ügyfélélményt. A szolgáltatás használatakor az ingatlanportál mindkét megkérdezett munkatársa ütközött nehézségekbe, de nem ítélték meg bonyolultabbnak a szolgáltatás használatát, mint más szolgáltatott szoftver esetében.
A kutatás második szakaszában a triád interjú során feltérképeztük, hogy mely minőségi webhelyanalitikai adatok hatására milyen változtatásokat eszközölt a vállalat a weboldal felépítésével kapcsolatban. Ezt követően összehasonlítottuk a változtatásokhoz kapcsolható mennyiségi és minőségi webhelyanalitikai adatokat a redesign előtti és utáni három hónapra vonatkozóan.

A triád interjú során a weboldal elemzését a főoldallal kezdtük. A vállalat termékmenedzsere bemutatta nekünk, hogy a részletes kereső felépítését mely munkamenet felvételek és kattintási hőtérképek alapján változtatták meg. Az adott munkamenet felvételeken jól látszik, hogy a felhasználók sokat időznek egy-egy szürési feltétel mellett, valamint sokszor visszatérnek egy-egy szürési feltételhez és átállítják azt. A részletes keresőről készült kattintási hőtérképeken -melyek egy aloldalon megjelenítik a kattintási sürüséget- feltünő, hogy a "kevésbé fontos és nagyon fontos kategóriák felváltva követik egymást a keresőben", pl. míg az árat, az alapterületet és a szobák számát a legtöbb ingatlankereső megadta, a telekméretet, az építés évét, valamint az emeletet elhanyagolható mennyiségü ember adta meg, mint keresési paraméter. A webhelyanalitikai eszköz hatására az ingatlanportál a legtöbb ember számára hasznos szürési feltételeket előre és egy blokkba rendezte. A redesign utáni három hónapból származó felhasználók munkameneteiről készült felvételeken már sokkal magabiztosabbnak tünnek a felhasználók, ritkán tértek vissza vagy módosítottak egy adott szürési feltételt, valamint a keresési paraméterek beállításával töltött idő is lecsökkent. A redesign utáni időszak részletes keresőről készült hőtérképein egyértelműen megállapítható, hogy az elöre és egy blokkba rendezett paraméterekre a felhasználók közül lényegesen többen kattintanak, mint az utána következő blokk paramétereire.

A redesign előtti "scroll" hőtérképekről -amelyek azt mutatják meg, hogy a felhasználók egy adott oldalon meddig görgetnek le- kiderült, hogy a felhasználók kevesebb mint $25 \%$-a látja a főoldali kiemelt ingatlanokat. Ennek hatására a föoldalon feljebb kerültek a kiemelt hirdetések, így a redesign után már a főoldali látogatók $40 \%$-a látta azokat. A mennyiségi webhelyanalitikai adatok alapján a versenytársakéhoz képest magasabb visszafordulási arány volt tapasztalható, így az oldal grafikai megjelenésében (házak, bútorok megjelenítése a főoldalon, a lista oldalakon és az adatlapi oldalokon) a listing portál egyértelmúvé szerette volna tenni, hogy ingatlanhirdetések találhatóak az oldalon. A visszafordulási arány 7\%-kal csökkent az oldal redesign-jának hatására. 
Az oldal átalakítását megelőző mennyiségi webhelyanalitikai adatok alapján az ingatlanportál visszatérő felhasználóinak aránya szignifikánsan alacsonyabb volt, mint a portál versenytársainak. A jobban azonosítható megjelenés kialakítása mellett az ingatlanportál jobban látható helyre helyezte a regisztráció és bejelentkezés gombokat, valamint a kedvenc keresések funkciót átláthatóbbá tette a visszatérő felhasználók arányának növelése érdekében. A kedvenc keresések funkció kattintási hőtérképén jól látható, hogy egyes alfunkciók teljesen kihasználatlanok, nem érkeznek rájuk kattintások. Az is jól kirajzolódott a kattintási hőtérképen, valamint a munkamenet visszajátszások során szintén szembetünő volt, hogy bár egyes alfunkciókat nem használnak a felhasználók, olyan helyekre próbálnak kattintani, amelyek nem kattinthatók. Az említett minőségi webhelyanalitikai adatok alapján az ingatlanportál teljesen megváltoztatta a funkció felépítését, közismert weboldalak és közösségi média portálok hasonló funkcióinak felépítését vette alapul, abban bízva, hogy az ismerős felépítést könnyebben kezelik a felhasználók. A változtatások hatására a mennyiségi webhelyanalitikai adatok alapján nőtt azon felhasználók száma, akik bejelentkezve használták az oldalt, a kedvenc keresések funkciót is nagyobb arányban kezdték el használni a felhasználók és feltehetően emiatt, a visszatérő felhasználók aránya is szignifikánsan nőtt.
A visszatérő felhasználók arányának növekedése ezen kívül az szolgáltatott szoftver adatai alapján történő adatlapi oldalakon történt változtatásoknak is tulajdonítható. Az ingatlan adatlapi kattintási hőtérképeken jól látható volt, hogy a kedvenc ingatlan funkciót a felhasználók töredéke használja csak. Az interjú során kiderült, hogy a kedvenc keresés és kedvenc ingatlan funkciók hivatottak visszahozni a felhasználókat a weboldalra, az adott ingatlan adatainak változásáról, valamint a keresési paramétereknek megfelelő új ingatlanokról az ingatlanportál elektronikus levelet küld a felhasználóknak. A kedvenc ingatlan funkciót szintén a népszerü weboldalakon megszokott struktúra szerint alakította át az ingatlan portál, amivel növelni tudja a kedvenc ingatlan funkció felhasználóinak számát.

\section{KÖVETKEZTETÉS CONCLUSION}

Az eredményalapú mérési módszer holisztikusan vizsgálja az ügyfélélményt, nemcsak azt vizsgáltuk meg esettanulmányunk során, hogy az adott vállalatnak tetszett-e a szolgáltatás igénybevétele, hanem hogy maga a szolgáltatás milyen eredményeket idézett elő a vállalat számára.

A triád interjúból kiderült, hogy amikor az ingatlanportál termékmenedzsere és tulajdonosa először látogatott el a szolgáltatott szoftver weboldalára, összességében semleges véleménnyel voltak arról (1. táblázat).

1.táblázat: Az ingatlanportál munkatársainak megítélése a szolgáltatott szoftverről a hagyományos ügyfélélmény-mérés alapján (negatív, pozitív, semleges)

Table 1. The opinions of the employees of the real estate portal based on the traditional customer experience measurement (negative, positive, neutral)

\begin{tabular}{|l|c|c|}
\hline \multicolumn{1}{|c|}{ Érintkezési pontok } & Tulajdonos & Termékmenedzser \\
\hline Termékoldalak & 0 & + \\
\hline Blog & + & - \\
\hline Elöfizetési csomagok & - & - \\
\hline Beállítások & - & + \\
\hline Ügyfélszolgálat & + & 0 \\
\hline Szolgáltatás használata & 0 & + \\
\hline
\end{tabular}

Forrás: saját kutatás 
Egy hagyományos elégedettség- vagy élménykutatás csupán a termék vagy szolgáltatás használatáig, illetve vásárlás utáni folyamatokig terjed (Zolkiewski et al. 2017). A hagyományos mérési módszerek alapján az ingatlanportál elégedettlen a szolgáltatással és egységes ügyfélélményt kizárólag az ügyfélszolgálat idézett elő a vállalatnál. Ezzel szemben a szolgáltatás használatának kimenetelit tanulmányozva az ingatlanportál munkatársai elégedettek a szolgáltatással, hasznosnak ítélték meg azt. A webhelyanalitikai adatok alapján a szolgáltatás nagymértékben hozzájárult az ingatlanportál ügyfélélményének kialakításában.

\section{A KUTATÁS KORLÁTAI, TOVÁBBI KUTATÁSI IRÁNYOK LIMITATIONS OF THE RESEARCH, FURTHER RESEARCH DIRECTIONS}

A triád interjú és a szolgáltatás tényleges igénybevétele között másfél év telt el. Bár a szolgáltatott szoftver üzemeltetői az ingatlanportál tulajdonosának beleegyezésével a rendelkezésünkre bocsátották azokat a minőségi webhelyanalitikai adatokat, amelyek segítették a portál munkatársai számára a visszaemlékezést, a szolgáltatás igénybevétele után közvetlenül készített interjú pontosabb eredményeket mutatott volna. A tanulmány során csupán azon érintkezési pontok véleményezésére tértünk ki, amelyekre az interjúalanyok vissza tudtak emlékezni, így például a vásárlást megelőző "prepurchase" periódus érintkezési pontjait nem tudtuk megvizsgálni. Kutatásunkban csak egy business-to-business kapcsolatot mutattunk be, viszont megalapozott következtetések levonásához további partnerkapcsolatokat kell tanulmányozni.

További kutatási célunk az eredményalapú ügyfélélmény-mérési módszer további weboldalakon történő megvizsgálása és a kapcsolat meghatározása az igénybevétel előtti elégedettség és ügyfélélmény, a vállalatra gyakorolt eredményesség és a felhasználó vagy igénybe vevő integrált ügyfélélménye és elégedettsége között. Feltételezésünk szerint az igénybevétel előtti ügyfélélmény kisebb hatással van az integrált ügyfélélményre, mint az eredményesség.

\section{HIVATKOZÁSOK REFERENCES}

Abbott, L. (1956), "Quality and Competition, An Essay in Economic Theory", Southern Economic Journal, 20(4), 501-503. DOI: 10.2307/1054542

Benlian, A. and Hess, T. (2011), "Opportunities and risks of Software-as-a-Service: Findings from a survey of it executives", Decision Support Systems, 52(1), 232-246. DOI: 10.1016/j.dss.2011.07.007

Benlian, A., Koufaris, M. and Hess, T. (2011), "Service quality in Software-as-a-Service, Developing the SaaS-Qual measure and examining its role in usage continuance", Journal of Management Information Systems, 28(3), 85-126. DOI: 10.2753/mis0742-1222280303

Bibi, S., Katsaros, D. and Bozanis, P. (2012), 'Business application acquisition, Onpremise or SaaSbased solutions?", IEEE Software, 29(3), 86-93. DOI: $10.1109 / \mathrm{ms} .2011 .119$

Biedenbac, G. and Marell, A. (2010), "The impact of customer experience on brand equity in a business-to-business services setting", Brand Management, 17(6), 446-458. DOI: 10.1057/bm.2009.37

Bonfiglio, N., Alon, M. and Pono, M (2017), 'Mastering Product Experience in SaaS: How to Deliver Personalized Product Experiences with Product-led Go-to-Market Strategy", Aptrinsic. https,// intrinsicpoint.com/mastering-product-experience-in-saas/home (letöltve: 2018.12.11.)

Burkett, H. (2013), "Moving from outputs to outcomes in the public health sector: a case study", Journal of the Grant Professionals Association, 11(1), 84-95

Edelman, D. C. and Singer, M. (2015), "Competing on Customer Journeys", Harvard Business Review, 93(11), 88-94

Lemon, K. N. and Verhoef, P. C. (2016), "Understanding Customer Experience Throughout the Customer Journey", Journal of Marketing, 80(6), 69-96. DOI: $10.1509 / \mathrm{jm} .15 .0420$

Lilien, G. L. (2016), "The B2B Knowledge Gap", International Journal of Research in Marketing, 33(3), 543-556. DOI: 10.1016/j.ijresmar.2016.01.003

McColl-Kennedy, J.R., Gustafsson, A., Jaakkola, E., Klaus, P., Radnor, Z., Perks, H. and Friman, M. (2015), "Fresh perspectives on customer experience", Journal of Services Marketing, 29(6-7), 430-435. DOI: 10.1108/jsm-01-2015-0054

Meyer, A., Christopher, A. and Schwager, A. (2007), "Understanding Customer Experience", Harvard Business Review, 85, 85-89.

Richardson, A. (2010), 'Using customer journey maps to improve customer experience", Harvard Business Review, 15(1), 2-5.

Schmitt, B. (1999), "Experiential Marketing: A New Framework for Design and Communications", New York, The Free Press, Spring, 10(2), 10-16. DOI: 10.1111/j.1948-7169.1999.tb00247.x

Shaw, C. (2007), "The DNA of Customer Experience, How Emotions Drive Value”, New York: Palgrave Macmillan, DOI: 10.2501/s0265048708080128

Zolkiewski, J., Story, V., Burton, J., Chan, P., Gomes, A., Hunter-Jones, P., Robinson, W. (2017), "Strategic B2B customer experience management: the importance of outcomes-based measures", Journal of Services Marketing, 31(2), 172-184. DOI: 10.1108/JSM-10-2016-0350 
Gyulai Zsófia, PhD hallgató gyulai.zsofia@eco.u-szeged.hu

Révész Balázs, egyetemi docens reveszb@eco.u-szeged.hu

Szegedi Tudományegyetem Gazdaságtudományi Kar

\section{Applying the outcomes-based customer experience measurement method in the B2B market}

\section{THE AIMS OF THE STUDY}

In our study, we examined whether the customer experience of a business-to-business relationship could be influenced by the value that the service provider creates for the user. In our research work, we investigated the relationship between a listing portal and an integrated web analytics softwareas-a-service.

\section{METHODOLOGY}

In our research, we used a holistic and very novel approach to customer experience measurement, the outcomes-based measurement method, which only appeared in the marketing literature a few years ago. The new methodology implies that shifting towards outcomes-based interventions moves the question from Did they like it?" to a more tactical analysis, „What difference did it make?” (Burkett 2013, Zolkiewski et al. 2017).

Customer or user experience in B2B markets is even more complex than in B2C markets, so a combination of different data collection methods can produce better results (Biedenbach \& Marell 2010, Zolkiewski et al. 2017). For improving results, we observed quantitative and qualitative website analytics and held a triad interview.

\section{MOST IMPORTANT RESULTS}

According to traditional customer experience measurement methods, the real estate portal was dissatisfied with the integrated web analytics tool and only a customer service at the company produced a unified customer experience. In contrast, studying the outcome of using the service, real estate portal staff were pleased with the service and found it useful. According to website analytics data, the service has greatly contributed to the real estate customer experience.

\section{RECOMMENDATIONS}

The novelty of the study lies in the applied methodology, the result-based customer experience measurement method. It helps companies get a more complex picture of customer satisfaction by holistically examining it.

Keywords: outcomes-based measurement, B2B marketing, customer experience

Acknowledgement: Supported by the ÚNKP-19-3 New National Program of the Ministry for Innovation and Technology. 